\title{
Mitochondrial DNA variability in Drosophila simulans: quasi absence of polymorphism within each of the three cytoplasmic races
}

\author{
F. Baba-Aïssa*, \\ M. Solignac*, \\ N. Dennebouy $\dagger$ and \\ J. R. David*
}

\author{
* Laboratoire de Biologie et Génétique Evolutives, \\ CNRS, 91198 Gif-sur-Yvette cedex, France. \\ † Laboratoire de Biologie Générale, Université Paris \\ XI, 91405 Orsay cedex, France.
}

Nucleotide variability of mtDNA extracted from 144 isofemale lines collected in the whole range of $D$. simulans was analysed with 10-15 restriction enzymes and 73 lines were studied using one or a few enzymes. All clones were distributed into 3 mitochondrial genomes, sil, sill and sill. These types are allopatric and can define geographic races. Mixed populations occur only in Madagascar and Réunion, where silI and sill are found together. Among 40 sites detected with 10 enzymes, the variability of the coding region is extremely low, with one or no polymorphic restriction sites depending on the type. The control $\mathbf{A}+\mathbf{T}$-rich region is more variable in length and in restriction sites, and allows subtypes to be designated. Several lines were heteroplasmic for the length of the genome. These results are relevant to the evolutionary history of the species, its recent worldwide extension and to probable founder effects at the origin of each of the three types.

\section{INTRODUCTION}

Drosophila melanogaster and D. simulans are cosmopolitan, commensal and generalist colonizing species. They probably originated from a common Afrotropical ancestor a few million years ago (Lachaise et al., 1988) and have spread to most of the world in the recent past with the aid of human transport (David and Tsacas, 1981; Parsons, 1983). D. melanogaster shows great geographic variation (Lemeunier et al., 1986) and such "racial" differentiation may have allowed the colonization of places with very different climates. $D$. simulans is less studied but, for several traits, such as chromosomal polymorphism (Ashburner and Lemeunier, 1976), allozyme frequencies (Hyytia et al., 1985; Singh et al., 1987) thoracic trident pigmentation (Capy et al., 1988) and alcohol tolerance (David and Bocquet, 1975) appears to be genetically much less variable between populations.

Mitochondrial DNA provides interesting information because of its maternal inheritance. $D$. melanogaster is moderately variable for mtDNA (Hale and Singh, 1987) but for D. simulans, a preliminary analysis (Baba-Aïssa and Solignac, 1984) of 13 lines suggests the occurrence of three geographic types with a low level of variability within each. This work has now been extended to 217 mitochondrial genomes from natural populations in various parts of the world, some of which have been studied with a wider range of restriction enzymes.

\section{MATERIALS AND METHODS}

Two hundred and seventeen isofemale lines were studied. They originate (table 1) from all continents and a number of oceanic islands. Between 1 and 21 lines from each natural population were studied.

Because of its maternal inheritance, all the flies of an isofemale line share the same mtDNA. MtDNA was extracted from unfertilized eggs using the quick preparation technique of Solignac et al., $1986 a$. A large number of such eggs, on average 50,000 , were used for extraction. The first extractions were performed from unfertilized eggs, laid by a number of virgin females. The egg production of virgins is low and irregular, and a more efficient method, using an interspecific cross, was worked out. Males of $D$. mauritiana (a sibling species of 
Table 1 Geographic origin of the isofemale lines studied. $N=$ number of lines. (Lines which were not fully analysed but only typed, in parentheses.) Mitochondrial genomes were assigned to the three main types (I, II and III) and subtypes (letters) as defined in fig. 1 by the structure of the non-coding region (the letter $x$ is given to lines which were not assigned to a precise subtype). LH, length heteroplasmy; ARS, additional restriction site

\begin{tabular}{|c|c|c|c|c|}
\hline & & $N$ & Types and subtypes & Remarks \\
\hline $\begin{array}{l}\text { Europe } \\
(N=5)\end{array}$ & $\begin{array}{l}\text { Athens (Greece) } \\
\text { Sicilia (Italy) } \\
\text { Antibes (France) } \\
\text { Sevilla (Spain) } \\
\text { Leeds (U.K.) }\end{array}$ & $\begin{array}{l}1 \\
1 \\
1 \\
1 \\
1\end{array}$ & $\begin{array}{l}\mathrm{II} c \\
\mathrm{II} c \\
\mathrm{II} a \\
\mathrm{II} c\end{array}$ & HpaII ARS \\
\hline $\begin{array}{l}\text { Tropical Africa }) \\
(N=15)\end{array}$ & $\begin{array}{l}\text { Loua (Congo) } \\
\text { Brazzaville (Congo) } \\
\text { Yaoundé (Cameroon) } \\
- \text { (Ethiopia) } \\
\text { Nairobi (Kenya) } \\
\text { Mt Elgon (Kenya) } \\
\text { Mt Kenya (Kenya) }\end{array}$ & $\begin{array}{l}1 \\
1 \\
1 \\
1 \\
1 \\
5 \\
5\end{array}$ & $\begin{array}{l}\mathrm{II} c \\
\mathrm{II} c \\
\mathrm{II} d \\
\mathrm{II} c \\
\mathrm{II} c / e \\
1 \mathrm{II} b ; 4 \mathrm{II} c \\
2 \mathrm{II} c ; 1 \mathrm{II} e ; 1 \mathrm{II} q ; 1 \mathrm{II} c / e\end{array}$ & $\begin{array}{l}\mathrm{LH} \\
\mathrm{LH}\end{array}$ \\
\hline $\begin{array}{l}\text { Southern Africa } \\
(N=40)\end{array}$ & $\begin{array}{l}\text { Cape Town (S. Africa) } \\
\text { Nysvley (S. Africa) } \\
\text { Victoria Falls (Zimbabwe) } \\
\text { Mwansa-(Tanzania) }\end{array}$ & $\begin{array}{c}21(15) \\
1 \\
1 \\
2\end{array}$ & $\begin{array}{l}2011 c, 111 b ; 15 \mathrm{II} x \\
11 c \\
\mathrm{II} c \\
\mathrm{II} b ; \mathrm{II} c\end{array}$ & \\
\hline $\begin{array}{l}\text { Middle East } \\
(N=17)\end{array}$ & $\begin{array}{l}\text { Bagdad (Iraq) } \\
\text { Teheran (Iran) }\end{array}$ & $\begin{array}{l}8 \\
9\end{array}$ & $\begin{array}{l}5 \mathrm{II} c ; 1 \mathrm{II} q ; 1 \mathrm{II} i ; 1 \mathrm{II} c / f \\
8 \mathrm{II} c ; 1 \mathrm{II} b\end{array}$ & LH \\
\hline $\begin{array}{l}\text { America } \\
(N=10)\end{array}$ & $\begin{array}{l}\text { Florida (U.S.A.) } \\
\text { South Amherst (U.S.A.) } \\
\text { Archibald (U.S.A.) } \\
\text { Carmel (U.S.A.) } \\
\text { Mapimi (Mexico) } \\
\text { - (Panama) } \\
\text { Cayenne (French Guyana) } \\
\text { Porto Allegro (Brazil) }\end{array}$ & $\begin{array}{l}1 \\
1 \\
1 \\
1 \\
3 \\
1 \\
1 \\
1 \\
1\end{array}$ & $\begin{array}{l}\mathrm{II} c \\
\mathrm{II} a \\
\mathrm{II} c \\
\mathrm{II} c \\
\mathrm{II} c \\
\mathrm{II} c \\
\mathrm{II} c \\
\mathrm{II} c\end{array}$ & \\
\hline $\begin{array}{l}\text { Indian Ocean region } \\
(N=84)\end{array}$ & $\begin{array}{l}\text { Mont-d'Ambre (Madagascar) } \\
\text { Antananarivo (Madagascar) } \\
\text { Réunion Island } \\
\text { Comoro Islands } \\
\text { Mahé (Seychelles) }\end{array}$ & $\begin{array}{l}1 \\
15 \\
3(37) \\
5 \\
16(21)\end{array}$ & $\begin{array}{l}\text { III } a \\
8111 a ; 711 h \\
3111 a ; 35111 x ; 211 x \\
\text { II } c \\
81 a ; 221 b ; 31 d ; 31 a / b ; 11 b / d\end{array}$ & SacI ARS LH \\
\hline Pacific Ocean islands & $\begin{array}{l}\text { Ogasawara (Japan) } \\
\text { Hawaii (U.S.A.) } \\
\text { Moorea (French Polynesia) } \\
\text { Nouméa (New Caledonia) }\end{array}$ & $\begin{array}{r}1 \\
7 \\
11 \\
6\end{array}$ & $\begin{array}{l}\mathrm{II} c \\
6 \mathrm{I} b ; 1 \mathrm{I} c \\
9 \mathrm{I} b ; 1 \mathrm{l} e ; 1 \mathrm{Ib} / \mathrm{d} \\
6 \mathrm{I} b\end{array}$ & $\begin{array}{l}\text { LH } \\
\text { SacI ARS }\end{array}$ \\
\hline
\end{tabular}

D. simulans) mate readily with $D$. simulans females, producing sterile F1 males but fully fertile females (David et al., 1974, 1976). Keeping the F1 flies together provides many unfertilized eggs with D. simulans cytoplasm.
The extracted DNA was digested with restriction enzymes. In our preparations, contaminant nuclear DNA amounts to about half of the total (Goldring and Peacock, 1977). Because of its complexity, this is digested into numerous fragments 
of diverse sizes which, after electrophoresis, produce a slight smear on the gels. By contrast, mtDNA is cut into a few, well defined fragments which are clearly identified.

Ten restriction enzymes were used to study 144 lines. They are AccI, BglII, EcoRI, HaeIII, HindIII, HpaI, HpaII, PvuII, SacI, XbaI. Five additional enzymes ( $A v a \mathrm{I}, A v a \mathrm{II}, B c l \mathrm{I}, C l a \mathrm{I}$ and EcoRV) were used on a smaller subsample of 30 isofemale lines. The remaining 73 lines, originating from South Africa (15 lines), Réunion Island ( 37 lines) and the Seychelles (21 lines) were analysed with only a few diagnostic enzymes in order to identify their mitochondrial type (see results section).

Restriction fragments were separated by electrophoresis either on 1 per cent agarose or on 5 per cent polyacrylamide gels. After staining with ethidium bromide, each gel was photographed under UV light. For AccI digestions, restriction fragments were radioactively end-labelled and the restriction fragments revealed by autoradiography.

Pairwise nucleotide distances $\pi_{i j}$ were calculated between all variants (types and subtypes) using the formulae of Nei and Li (1979). Nucleotide diversity $\pi$ was estimated, using the weighted average of pairwise nucleotide distances.

\section{RESULTS}

\section{The three mitochondrial DNA types}

The mitochondrial genomes of the 144 lines studied here with 10 or 15 enzymes (and by inference those of the 73 additional lines) can be assigned to three geographically distinct main types, siI, siII and siIII. Their restriction maps have been published by Solignac and Monnerot (1986) and Solignac et al. (1986a). Six restriction enzymes, AccI, ClaI, Eco RI, Eco RV, HpaI and Hpa II are diagnostic. They provide characteristic electrophoretic profiles so that any mtDNA digested with one of these enzymes can be unambiguously assigned to one of the types.

In the coding region of the mtDNA, the types differ by 10 to 15 restriction sites among the 40 or so identified in the present study. Within a given type, variability is absent or is restricted to a single site. In the $\mathrm{A}+\mathrm{T}$-rich region variations are observed between the three types and also within two of them, allowing the definition of subtypes (fig. 1). This region comprises a domain harbouring a sequence of $470 \mathrm{bp}$ which is repeated from two to four times in direct tandem. Each repeated unit typically shows an $\mathrm{Hpa}$ I and an $A c c$ I site, mapped very close together. One of these two sites may be absent in one, several or even all of these units. The repeated region is flanked by domains whose lengths are also variable (see Solignac et al., 1986b).

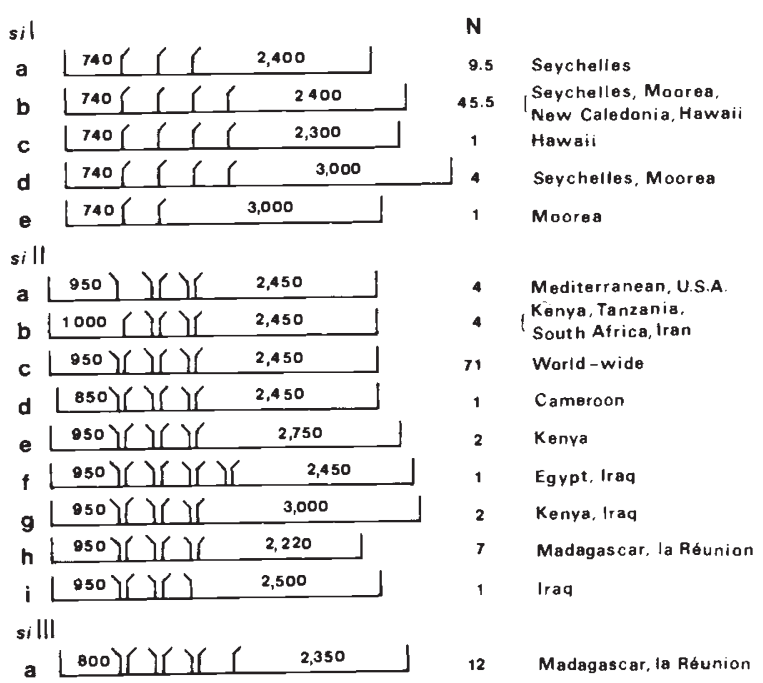

Figure 1 Structure of the A+T-rich, non-coding region in three types of mitochondrial genomes. The region shown, slightly larger than the control region itself, is flanked on the left by a HindIII restriction site within the ND2 gene and, on the right, by a Tha I site within the small subunit of the ribosomal RNA. The HpaI sites are indicated by left-leaning sticks and $A c c$ I sites by right-leaning sticks.

These sites are included in a repeated unit of $470 \mathrm{bp}$. The domains on the left and right of the repeated sequences are variable in length. Within each main type (I, II, III) structural subtypes are designated by letters. For each of them the number of lines (N) observed and the geographic origin are indicated. The size of double digest fragments is indicated in base pairs.

\section{The sil type}

All the flies originating from the following populations: Seychelles (37 lines), New Caledonia (6 lines), Moorea (11 lines) and Hawaii (7 lines) belong to the sil type. No other type was detected on these islands and no si I mtDNA was found in the other populations studied (table 1).

In the coding region, only one polymorphic site was observed. This corresponds to an extra SacI site found in two lines from New Caledonia and one from the Seychelles. The 13 lines analysed with five additional enxymes did not show any further variant. 
Length variations in the $\mathrm{A}+\mathrm{T}$-rich region (fig. 1) allowed the definition of five subtypes ( $a$ to $e$ ). There is variation in the number of repeated sequences ( 2 to 4 units) and in the length of the domain located to the right of these sequences. $s i \mathrm{I} b$ is always the commonest subtype. The other subtypes are each present only on one island (except siId, which is found on Mahé and Moorea).

Five out of 61 lines were heteroplasmic for genome length: three lines had the structure $a / b$ and two the structure $b / d$ (table 1 ; fig. 1 ).

\section{The sill type}

This widespread genome was found in 109 lines from Africa, Europe, America, the Middle East, Australia and Japan where all lines belonged to the silI type. It was also found in Madagascar (7 out of 16 lines) and in Réunion ( 2 out of 40). Type II is hence almost a worldwide genome and may well comprise more than 95 per cent of the individuals and populations of this cosmopolitan species (fig. 2).
Only one polymorphic site was detected in the coding region of the 92 lines analysed with a complete set of 10 enzymes: it is an additional Hpa II site found, in an English line from Leeds (the same variant was found in a Italian line by Nigro, 1988). Five additional enzymes used on 15 lines failed to evidence any extra variation.

The non coding region (fig. 1) was more variable, as its length varies with the number of repeated units ( 3 or 4 ) and with the size of domains to the right or left of the repeated region. There is a polymorphism in the repeated units, for one $H p a I$ and two $A c c$ I sites. Nine subtypes, $a$ to $i$, can be distinguished. The $c$ subtype is the most common (72 per cent). Among 92 genomes, four cases of length heteroplasmy were observed: two (Egypt and Iraq) with the $c / f$ structure and two (Kenya) with $c / e$.

\section{The sill type}

This is found in Réunion (38 lines out of 40) and in Madagascar (nine out of 16). Ten lines were studied with 10 enzymes and two with 15 enzymes

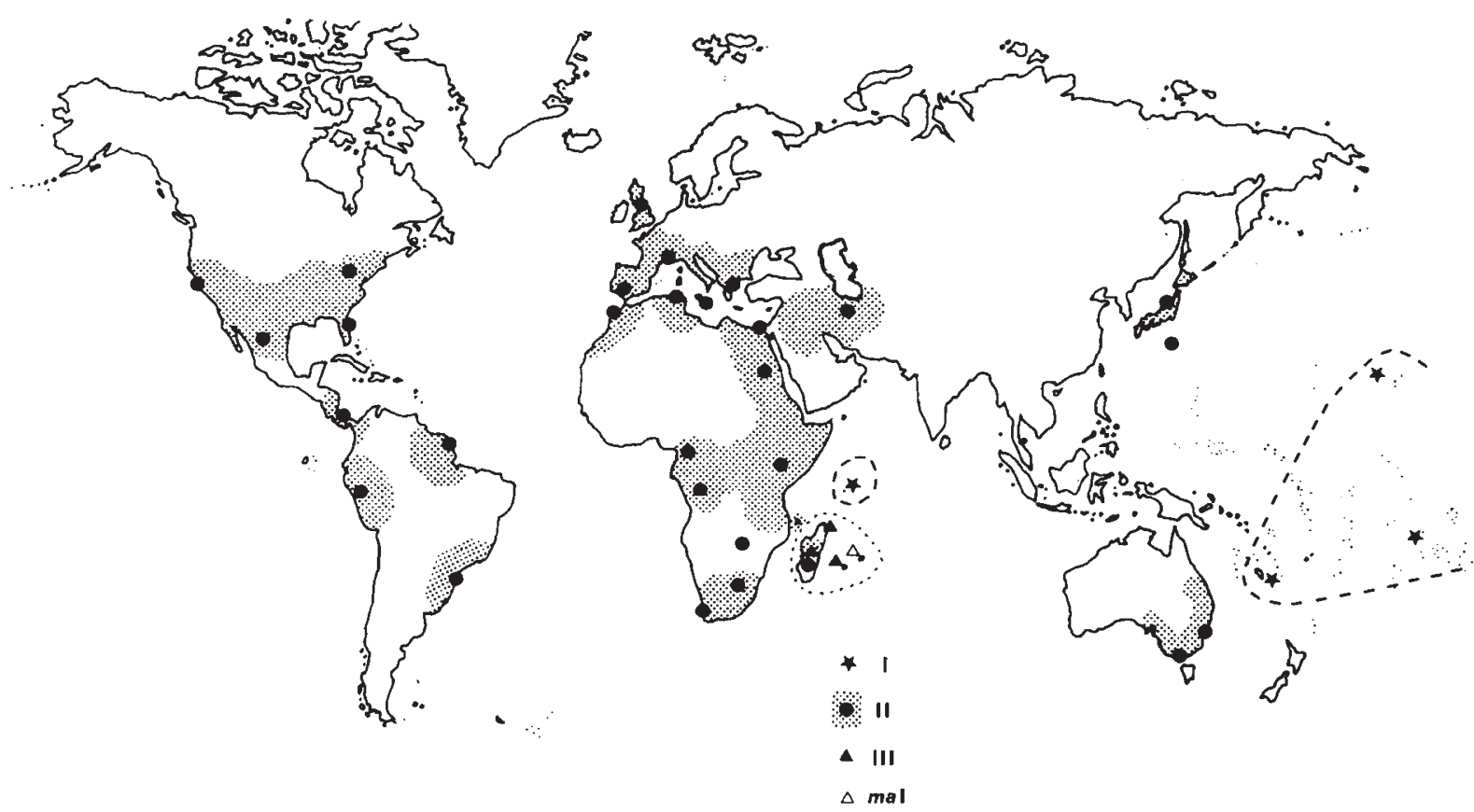

Figure 2 Distribution of mtDNA types in $D$. simulans. Type si I is restricted to the Seychelles, New Caledonia, Polynesia and Hawaii. Type siIII is found only in Madagascar and Réunion but occurs also in the sibling species $D$. mauritiana in Mauritius. Type SiII is worldwide and, around each locality, a dotted area shows the presumed extension of the population. Localities are shown in table 1 and results from other authors have been included: North Carolina and Japan (Shah and Langley, 1979a); California and Peru (Fauron and Wolstenholme, 1980 b); Italy, Netherland, Spain and Morocco (Nigro, 1988). 
(three from Réunion and nine from Madagascar) but no variant was detected either for the restriction sites or for the genome length. The non coding region always harbours four repeated sequences (fig. 1).

This silI type is identical, with respect to restriction sites and structure of the A+T-rich region, to the long $m a$ I genome which exists in $D$. mauritiana (Solignac et al., 1983).

\section{Polymorphism and nucleotide distances}

Data on a polymorphism (excluding the 73 lines only assigned to a given type and results obtained with the five additional enzymes) are summarized in table 2. Polymorphism is calculated for the coding region, the non-coding region and the complete genome. In the $\mathrm{A}+\mathrm{T}$-rich region, the alignment of HpaI and AccI sites cannot be directly done when the number of repeated units are different from the commonest genome that carries three repeated sequences (fig. 1). For this reason, in order to allow alignment, one unit has been taken off in the genomes which have four units ( $s i \mathrm{I} b, c, d, \operatorname{sil} f$ and $\operatorname{silI} a$ ) and the single genome where only two units are found (siIe) has been considered as possessing an additional (fictitious) unit with one $H p a$ I site. In table 2, the three main mitochondrial types are subdivided into groups which take account of site variations in the subtypes. Within each type, the distances between subtypes are extremely low. As expected, distances

Table 2 Matrices of restriction site numbers (on and above diagonal) and of nucleotide distances (below). Mitochondrial subtypes are distinguished, within each type, according to variation in the non coding region (see fig. 2). In siI type, a subtype SacI+ is distinguished by an extra restriction site (three lines). In siII $c$ one line exhibited an additional Hpa II site. Numbers of lines are given for each type. In each box the first row corresponds to the non coding region, the second row to the coding region, the third to the total genome.

On the diagonal: number of restriction sites observed with 4-, 5- and 6-cutter enzymes.

Above the diagonal: number of restriction sites in common between types and subtypes, using the three classes of enzymes.

Below the diagonal: nucleotide distances (\%) calculated according to Nei and Li (1979).

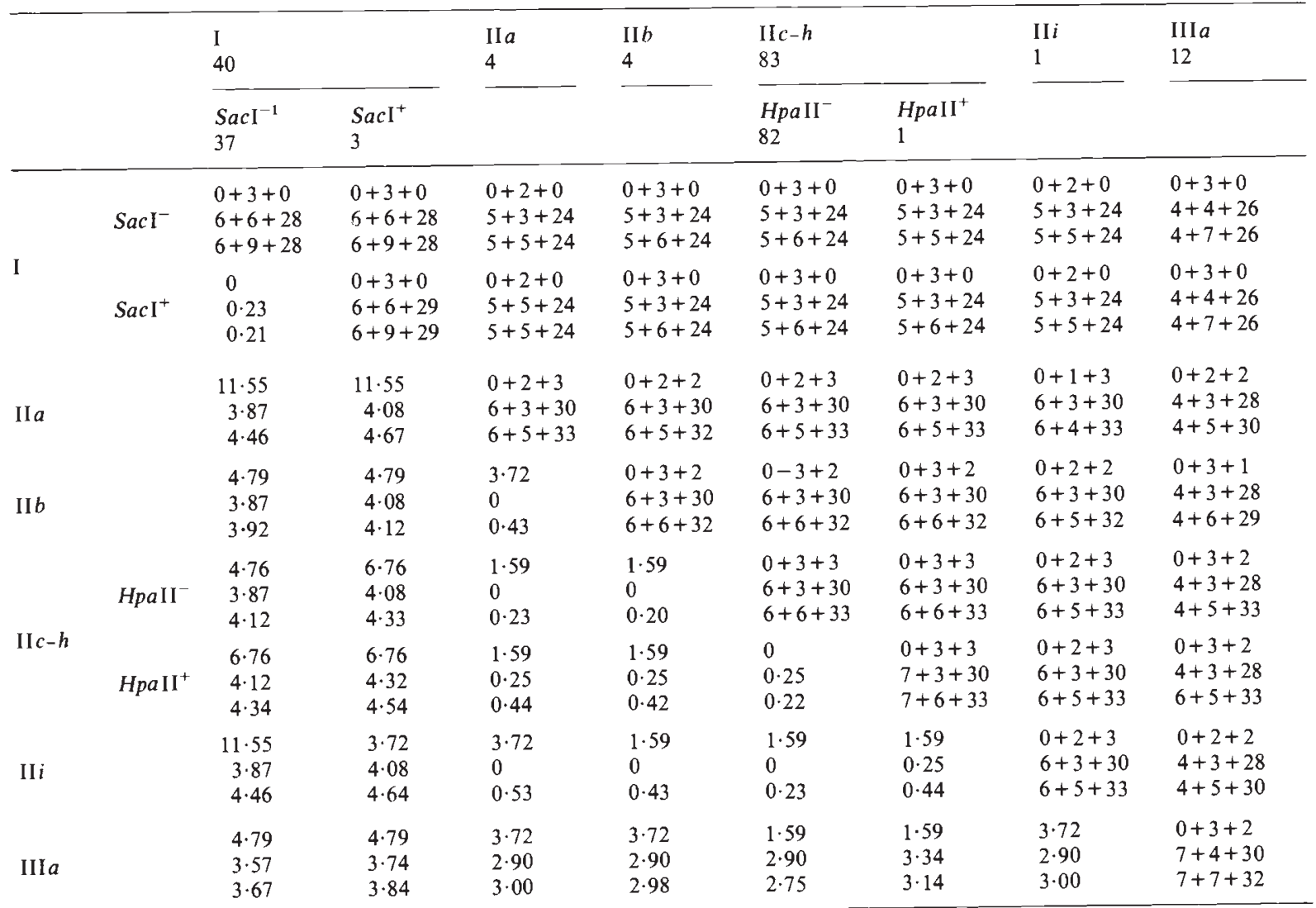


between types are much higher, siII and siIII being closer between them than with siI.

The nucleotide diversity, $\pi$, is given in table 3 . This has been calculated for some natural populations (e.g., Seychelles, Cape Town) when the sample size was sufficient, for distinct geographic regions (e.g., Europe, Africa, etc.), for each of the three types, and for the whole species. Within each type, the diversity is very low, on the average 0.030 per cent. It is much higher (1.98 per cent) for the whole species.

Table 3 Nucleotide diversity ( $\pi$ of Nei and Tajima, 1981) in the mitochondrial genome of $D$. simulans. The results are presented according to the country of origin (when a sufficient number of lines were available), to larger geographic regions, to mitochondrial types or to the whole species. Values are calculated for the coding region and the total genome, and are expressed in percentages. The number of lines is given in parentheses

\begin{tabular}{lll}
\hline & $\begin{array}{l}\text { Coding } \\
\text { region }\end{array}$ & $\begin{array}{l}\text { Total } \\
\text { genome }\end{array}$ \\
\hline $\begin{array}{l}\text { Country of origin } \\
\text { Seychelles (16) }\end{array}$ & 0.029 & 0.026 \\
$\begin{array}{l}\text { Southern Africa (25) } \\
\text { Madagascar (16) }\end{array}$ & 0.000 & 0.031 \\
Geographic regions & 1.523 & 1.444 \\
$\quad$ Europe (5) & & \\
Africa (45) & 0.100 & 0.179 \\
Middle East (17) & 0.000 & 0.045 \\
America (10) & 0.000 & 0.051 \\
mt DNA types & 0.000 & 0.046 \\
type I (40) & & \\
type II (92) & 0.033 & 0.030 \\
type III (12) & 0.006 & 0.046 \\
Whole species (144) & 0.000 & 0.000 \\
\hline
\end{tabular}

\section{DISCUSSION}

There are three main, well differentiated and mostly allopatric mtDNA types in $D$. simulans with a very low genetic polymorphism within each of them. These can bu related to the past evolutionary history of the species and also to its population dynamics and recent colonizing history.

Each mitochondrial type occupies a distinct geographic area. Type II, found in almost all temperate and tropical continental areas and in many islands, is almost worldwide. The two other types are only found on a few islands: type siIII only on Madagascar and its neighbour, Réunion and si I is from four areas separated by up to $17,000 \mathrm{~km}$. Only in Madagascar and Réunion are two types (II and III) found in sympatry.
The domestic status of $D$. simulans suggests that the occurrence of two types on these islands may be a consequence of recent introductions, with siIII (endemic to this region), as the native population and sill (represented by the $h$ endemic subtype of unknown origin), being a recent colonizer. The three groups of populations are three cytoplasmic geographic races within $D$. simulans. Hybridization experiments between races do not show any incipient isolation (Lachaise et al., 1986 and unpublished).

In the coding region, intratype variants are very scarce: an additional $\mathrm{SacI}$ site was encountered in three individuals, belonging to the type I and an extra $H p a$ II site was found in a type II strain from Leeds. Variation is more common in the A+T-rich control region (fig. 1). The number of repeated units ranges from 2 to 4 , and the length of the domains at the left or the right of these units also shows some variability. Within the repeated units, there is a polymorphism of some $H p a \mathrm{I}$ and $A c c \mathrm{I}$ sites in sill clones: an observation which agrees with previous work on Drosophila (Shah and Langley, 1979b; Zakour and Bultmann, 1979; Fauron and Wolstenholme, 1980a; Clary and Wolstenholme, 1987).

Five-and-a-half per cent of variants were found in an heteroplasmic state. In the other Drosophila species, possessing a long mitochondrial genome, the frequency of heteroplasmic individuals is 18 per cent in D. mauritiana (Solignac et al., 1984 and $1986 a, b$ ), 12 per cent in $D$. sechellia (Solignac et al., $1986 b$ and unpublished) and 17 per cent in D. melanogaster (Hale and Singh, 1986).

Genetic variability in the $D$. simulans mtDNA ( $\pi=1.98$ per cent) (table 3 ) is within the range of values found in vertebrates (where the nucleotide diversity generally ranges between a few per thousand and a few per cent: Avise and Lansman, 1983; Boursot and Bonhomme, 1986; Avise et al., 1987 ) and in genus Drosophila: $1 \cdot 1$ per cent and 0.45 per cent for $D$. subobscura in the Old and New Worlds respectively (Latorre et al., 1986); $1 \cdot 1$ per cent for $D$. heteroneura and $D$. silvestris in Hawaii (from data of DeSalle et al., 1986, and formula 12 of Ewens et al., 1981), and $0 \cdot 2$ per cent in D. melanogaster (Hale and Singh, 1987).

However, the nucleotide diversity in $D$. simulans is almost entirely due to the existence of the inter-racial variability as intra-racial variability, for the coding regions is only $0.033,0.006$ and 0.000 per cent for si I, siII and siIII.

The world-wide siII race hence has a variability two or three levels of magnitude lower than the Hawaiian Drosophila which have a far smaller 
population size over a tiny geographic area. Some efficient process must have reduced mitochondrial variability in $D$. simulans.

Two stochastic processes may be involved: a severe bottleneck of short duration (founder effect) or long lasting genetic drift in a small population. We previously (Baba-Aïssa and Solignac, 1984) favoured the founder effect hypothesis for $D$. simulans as did Brown (1980) for human beings. This hypothesis has been criticized by several authors (Avise et al., 1984; Latorre et al., 1986) who defend the possibility of a chronic genetic drift. These processes cannot easily be distinguished by just considering the mitochondrial genome.

Contrary to earlier estimates, recent studies of intrapopulational enzymatic variability of $D$. simulans have shown almost as high a heterozygosity as that of D. melanogaster (Hyytia et al., 1985; Choudhary and Singh, 1987; Cariou, personal communication). The low mitochondrial variability within each race, associated with a normal heterozygosity of nuclear genes, is an argument in favour of founder event (see Wilson et al., 1985). The genetic drift necessary to reduce the mtDNA variability to its current level would be severe; for siII, the long term effective size would have to be around 1000 females (if we assume that $\pi$ is an estimate of $4 \mathrm{~N} \mu$, and accept, with DeSalle et al. (1987), that the mutation rate, $\mu=10^{-8}$ for Drosophila mtDNA). However, the genetic diversity of nuclear genes $(H=0 \cdot 09$, Choudhary and Singh, 1987) leads to an estimate of population size 100 times higher, according to the formula of Kimura and Crow (1964).

D. simulans probably originated in Eastern Africa (mainland or neighbouring Indian Oceanic islands) an hypothesis sustained by faunistic arguments (Lachaise et al., 1988), the presence of three mitochondrial genomes here and the two insular and closely related endemics $D$. mauritiana and D. sechellia (Solignac and Monnerot, 1986). D. simulans probably achieved its present world-wide distribution through human transport (David and Tsacas, 1981; Parsons, 1983; Lachaise et al., 1988). The recency of such an expansion is attested to by its mitochondrial monomorphism over large areas and by the great genetic similarities of the nuclear genomes of remote populations (Hyytia et al., 1985; Choudhary and Singh, 1987).

It is not clear whether man has propagated individuals from three monomorphic ancestral races, or if the different mitochondrial types all originated in a single ancestral polymorphic population. Founder effects are compatible with either hypothesis, but a dramatic genetic drift is unlikely to have preserved the three very different-and very ancient-mitochondrial types so that this second hypothesis seems unlikely.

Acknowledgements We thank the many people who helped to collect the populations: J. Van Alphen, M. L. Cariou, K. Kaneshiro, D. Lachaise, S. F. McEvey, L. Tsacas, S. Tsakas, J. Vouidibio, D. Van Waerebeke. This work benefited from grants from C.N.R.S. (R.C.P. No. 106) and P.I.R.E.N.

\section{REFERENCES}

ASHBURNER, M. AND LEMEUNIER, F. 1976. Relationships within the melanogaster species subgroup of the genus Drosophila (Sophophora). I. Inversion polymorphisms in Drosophila melanogaster and Drosophila simulans. Proc. $R$. Soc. Lond. B, 193, 137-157.

AVise, J. C. AND LANSMAN, R. A. 1983. Polymorphism of mitochondrial DNA in populations of higher animals. In Nei, M. and Koehn, R. K. (eds) Evolution of Gene and Proteins, Sinauer, Sunderland, Mass., pp. 147-164.

AVISE, J. C., NEIGEL, J. E. AND ARNOLD, J. 1984. Demographic influences on mitochondrial DNA lineage survivorship in animal populations. J. Mol. Evol., 20, 99-105.

AVISE, J.C., ARNOLD, J., BALL, R. M., BERMINGHAM, E., LAMB, T., NEIGEL, J. E., REEB, C. A. AND SAUNDERS, N. C. 1987. Intraspecific phylogeography: the mitochondrial DNA bridge between population genetics and systematics. Ann. Rev. Ecol. Syst., 18, 489-522.

BABA-AÏSSA, F. AND SOLIGNAC, M. 1984. La plupart des populations de Drosophila simulans ont problement pour ancêtre une femelle unique dans un passé récent. C.R.Acad. Sc. Paris, 299, 289-292.

BOURSOT, P. AND BON HOMME, F. 1986. Génétique et évolution du génome mitochondrial des Métazoaires. Génét. Sél. Evol., 18, 73-98.

BROWN, W. M. 1980. Polymorphism in mitochondrial DNA of humans as revealed by restriction endonuclease analysis. Proc. Natl. Acad. Sci. USA, 77, 3605-3609.

CAPY, P., DAVID, J. R. AND ROBERTSON, A. 1988. Thoracic trident pigmentation in natural populations of Drosophila simulans: a comparison with D. melanogaster. Heredity (in press).

CHOUDHARY, M. AND SINGH, R. S. 1987. A comprehensive study of genetic variation in natural populations of Drosophila melanogaster. III. Variations in genetic structure and their causes between Drosophila melanogaster and its sibling species Drosophila simulans. Genetics, 117, 697-710.

CLARY, D. O. AND WOLSTENHOLME, D. R. 1987. Drosophila mitochondrial DNA: conserved sequences in the A+T-rich region and supporting evidence for a secondary structure model of the small ribosomal RNA. J. Mol. Evol., 25, 116-125.

DAVID, J. R. AND BOCQUET, C. 1975. Similarities and differences in latitudinal adaptation of two Drosophila sibling species. Nature, 257, 588-590.

DAVID, J. R. AND TSACAS, L. 1981. Cosmopolitan, subcosmopolitan and widespread species: different strategies in the drosophilid family. C. R. Soc. Biogéog., 57, 11-86. 
DAVID, J., BOCQUET, C., LEMEUNIER, F. AND TSACAS, L. 1976. Persistence of male sterility in strains issued from hybrids between two sibling species, $D$. simulans and $D$. mauritiana. J. Genet., 62, 93-100.

DAVID, J., LEMEUNIER, F., TSACAS, L. AND BOCQUET, C. 1974. Hybridation d'une nouvelle espèce, Drosophila mauritiana, avec D. melanogaster et D. simulans. Ann. Génét., 17, 235-241.

DeSAlle, R., VAL Giddings, L. AND TEMPleton, A. R. 1986. Mitochondrial DNA variability in natural populations of Hawaiian Drosophila. I. Methods and levels of variability in $D$. silvestris and $D$. heteroneura populations. Heredity $56,75-85$.

DeSAlle, R., FReEdMAN, T., PRAGer, E. M. AND Wilson, A. C. 1987. Tempo and mode of sequence evolution in mitochondrial DNA of Hawaiian Drosophila. J. Mol. Evol., $26,157-164$.

EWENS, W. J., SPIELMAN, R. S. AND HARRIS, H. 1981. Estimation of genetic variation at the DNA level from restriction endonuclease data. Proc. Natl. Acad. Sci. USA, 78, 37483750 .

FAURON, C.M.-R. AND WOLSTENHOLME, D. R. 1980a. Extensive diversity among Drosophila species with respect to nucleotide sequences within the adenine thymine-rich region of mitochondrial DNA molecules. Nucleic Acids Res., 8, 2439-2452.

FAURON, C. M.-R. AND WOLSTENHOLME, D. R. 1980 b. Intraspecific diversity of nucleotides within the adenine+ thymine-rich region of mitochondrial DNA molecules of Drosophila mauritiana, D. melanogaster and D. simulans. Nucleic Acids Res., 8, 5391-5410.

GOLDRING, E. S. AND PEACOCK, W. J. 1977. Intramolecular heterogeneity of mitochondrial DNA of Drosophila melanogaster. J. Cell Biol., 73, 279-286.

HALE, L. R. AND SINGH, R. S. 1986. Extensive variation and heteroplasmy in size of mitochondrial DNA among geographic populations of Drosophila melanogaster. Proc. Natl. Acad. Sci., USA, 83, 8813-8817.

HALE, L. R. AND SINGH, R. S. 1987. Mitochondrial DNA and genetic structure in populations of Drosophila melanogaster. Mol. Biol. Evol., 4, 622-637.

HYYTIA, P., CAPY, P., DAVID, J. R. AND SINGH, R. S. 1985. Enzymatic and quantitative variation in European and African populations of Drosophila simulans. Heredity, 54, 209-217.

KIMURA, M. AND CROW, J. F. 1964. The number of alleles that can be maintained in a finite population. Genetics, 49, 725-738.

LACHAISE, D., DAVID, J. R., LEMEUNIER, F., TSACAS, L. AND ASHBURNER, M. 1986. The reproductive relationships of Drosophila sechellia with $D$. mauritiana, D. simulans and D. melanogaster from the Afrotropical region. Evolution, 40, 262-271.
LACHAISE, D., CARIOU, M. L., DAVID, J. R, LEMEUNIER, F. TSACAS, L. AND ASHBURNER, M. 1988. Historical biogeography of the Drosophila melanogaster species subgroup. Evol. Biol., 22, 159-225.

LATORRE, A., MOYA, A. AND AYALA, F. J. 1986. Evolution of mitochondrial DNA in Drosophila subobscura. Proc. Natl. Acad. Sci. USA, 83, 8649-8653.

LEMEUNIER, F., DAVID, J. R., TSACAS, L. AND ASHBURNER, M. 1986. The melanogaster species group. In Ashburner, M., Carson, H. L. and Thompson, J. N. (eds) The Genetics and Biology of Drosophila, Vol. 3e, pp. 147-256.

NEI, M. AND LI, W. H. 1979. Mathematical model for studying genetic variation in terms of restriction endonucleases. Proc. Natl. Acad. Sci. USA, 76, 5269-5273.

NIGRO, L. 1988 . Natural populations of Drosophila simulans show great uniformity of the mitochondrial DNA restriction map. Genetica, in press.

PARSONS, P. A. 1983. The Evolutionary Biology of Colonizing Species. Cambridge Univ. Press, Cambridge.

SHAH, D. M. AND LANGLEY, C. H. 1979a. Inter-and intraspecific variation in restriction maps of Drosophila mitochondrial DNAs. Nature, 281, 696-699.

SHAH, D. M. AND LANGLEY, C. H. 1979b. Electron microscope heteroduplex study of Drosophila mitochondrial DNAs: evolution of the A+T-rich region. Plasmid, 2, 69-78.

SINGH, R. S., CHOUdHARY, M. AND DAVID, J. R. 1987. Contrasting patterns of geographic variation in the cosmopolitan sibling species. Drosophila melanogaster and Drosophila simulans. Biochem. Genet., 25, 27-40.

SOLIGNAC, M., GENERMONT, J., MONNEROT, M. AND MOUNOLOU, J.C. 1984. Mitochondrial genetics of Drosophila: mtDNA segregation in heteroplasmic strains of D. mauritiana. Mol. Gen. Genet., 197, 183-188.

SOLIGNAC, M. AND MONNEROT, M. 1986. Race formation, speciation and introgression within the three homosequential species Drosophila simulans, D. mauritiana and $D$. sechellia inferred from their mitochondrial DNA analysis. Evolution, 40, 531-539.

SOLIGNAC, M., MONNEROT, M. AND MOUNOLOU, J.-C. 1983. Mitochondrial DNA heteroplasmy in Drosophila mauritiana. Proc. Natl. Acad. Sci. USA, 80, 6942-6946.

SOLIGNAC, M., MONNEROT, M. AND MOUNDOLOU, J.-C. 1986a. Mitochondrial DNA evolution in the melanogaster species subgroup of Drosophila. J. Mol. Evol., 23, 31-40.

SOLIGNAC, M., MONNEROT, M. AND MOUNOLOU, J.-C. $1986 b$. Concerted evolution of sequence repeats in Drosophila mitochondrial DNA. J. Mol. Evol., 24, 53-60.

WILSON, A. C., CANN, R., CARR, S. M., GEORGE, M., GYLLENSTEN, U. B., HELM-BYCHOVSKI, K. M., HIGUCHI, R. G., PALUMBI, S. R., PRAGER, E. M., SAGE, R. D. AND STONEKING, M. 1985. Mitochondrial DNA and two perspectives on evolutionary genetics. Biol. J. Linn. Soc, 26, 375-400.

ZAKOUR, R. A. AND BULTMANN, H. 1979. Evolution of Drosophila mitochondrial DNAs. Analysis of heteroduplex molecules. Biochem. Biophys. Acta, 564, 342-351. 